\title{
Wpływ drobnoziarnistej krzemionki na parametr czasu oczekiwania na cement - WOC
}

\section{The effect of fine-grained silica on the waiting on cement (WOC) parameter}

\author{
Marcin Kremieniewski \\ Instytut Nafty i Gazu - Państwowy Instytut Badawczy
}

\begin{abstract}
STRESZCZENIE: Podczas projektowania zaczynu cementowego przeznaczonego do uszczelniania kolumny rur okładzinowych jego parametry dobierane są w zależności od występujących warunków geologiczno-technicznych. Właściwości świeżego zaczynu powinny pozwalać na odpowiednie przetłoczenie go przez kolumnę rur w uszczelniany interwał przestrzeni pierścieniowej lub pozarurowej przy możliwie maksymalnym wyparciu płuczki oraz odpowiednim usunięciu pozostałości osadu. Czas gęstnienia oraz wiązania dobiera się w taki sposób, aby zaczyn rozpoczął wiązanie po wtłoczeniu go w uszczelnianą przestrzeń pierścieniową lub pozarurową. Po związaniu zaczynu następuje budowanie wczesnej wytrzymałości mechanicznej, a czas niezbędny do związania zaczynu określany jest mianem WOC ( $\mathrm{z}$ ang. waiting on cement - „czas oczekiwania na cement”). Wymaga się, aby wartość tego parametru była możliwie niska, co umożliwi wcześniejsze przystąpienie do dalszych prac i wiercenia kolejnego interwału. W związku z tym uzyskanie krótkiego czasu WOC jest bardzo korzystne z ekonomicznego punktu widzenia i trwają prace, aby parametr ten był skracany do minimum. Ze względu na powyższe wymagania, które są stawiane zaczynom cementowym wykorzystywanym do uszczelniania otworów wiertniczych, istnieje konieczność ciągłego doskonalenia stosowanych receptur, dlatego też badaniom poddawane są coraz nowsze materiały. Jednym $\mathrm{z}$ takich dodatków jest dwutlenek krzemu o bardzo dużej powierzchni właściwej, dzięki czemu wykazuje on korzystny wpływ na parametry technologiczne zaczynu. Ten właśnie rodzaj mikrokrzemionki został poddany badaniom, podczas których określono wpływ $\mathrm{SiO}_{2}$ na szybkość osiągnięcia wartości WOC, co zostało omówione w niniejszej publikacji. W trakcie realizacji prac badawczych, których celem było określenie wpływu drobnoziarnistej krzemionki na szybkość osiągnięcia wartości 3,5 MPa, czyli parametru WOC, wykonano badania dla czterech receptur zaczynów. Jedna z receptur to zaczyn kontrolny, który służył za punkt odniesienia, kolejne trzy zaczyny to składy zawierające odpowiednio 10\%, 20\% i 30\% drobnoziarnistej mikrokrzemionki SBC. Podczas badań wstępnych określono wpływ stosowanego dodatku na parametry technologiczne świeżego zaczynu. Następnie skoncentrowano się na wartościach wczesnej wytrzymałości mechanicznej stwardniałego zaczynu. Badania prowadzono za pomocą metody nieniszczącej przy użyciu $\mathrm{UCA}^{1} \mathrm{w}$ warunkach otworopodobnych (temperatura $30^{\circ} \mathrm{C}$ i ciśnienie $5 \mathrm{MPa}$ ). Określono wytrzymałość na ściskanie po upływie ustalonego czasu (12, 42, 48 godzin) oraz czas, po jakim uzyskano wymagane wartości wytrzymałości na ściskanie (3 MPa, 3,5 MPa, $4 \mathrm{MPa}, 10 \mathrm{MPa}$ ). Na podstawie otrzymanych wyników określono wpływ dodatku drobnoziarnistej mikrokrzemionki na parametr WOC, czyli na szybkość osiągnięcia wartości wytrzymałości 3,5 MPa.
\end{abstract}

Słowa kluczowe: receptura zaczynu cementowego, czas oczekiwania na cement, wytrzymałość na ściskanie, mikrokrzemionka, dodatek drobnoziarnisty, ultradźwiękowy analizator cementu.

ABSTRACT: When designing a cement slurry for sealing a column of casing pipes, its parameters are selected depending on the geological and technical conditions. The properties of the fresh cement slurry should be that it can be properly forced through the column of pipes into the interval of the annular space being sealed with the possible maximum removal of the drilling mud. The thickening and setting time is selected in such a way that the cement slurry begins to set after being pressed into the annular space being sealed. When the slurry is set, early mechanical strength starts to build up. The time needed for the cement slurry to set is called WOC (waiting on cement). The value of this parameter should be as short as possible, thus allowing for earlier commencement of further work and drilling of the next interval. Therefore, obtaining a short WOC time is very beneficial from an economic point of view and work is underway to keep this parameter to a minimum. Due to the above requirements, which are posed by cement slurries used to seal boreholes, it is necessary to continuously improve the recipes used, which is why newer materials are being tested. One of such additions is silicon dioxide with a very large specific surface area, thanks to which it has a beneficial effect on the technological parameters of the cement

\footnotetext{
${ }^{1} \mathrm{UCA}$ - ultradźwiękowy analizator cementu
}

Autor do korespondencji: M. Kremieniewski, e-mail: marcin.kremieniewski@inig.pl

Artykuł nadesłano do Redakcji 28.06.2019 r. Zatwierdzono do druku 11.10.2019 r. 
slurry. This type of microsilica has been studied and the effect of $\mathrm{SiO}_{2}$ on the rate of reaching WOC value has been determined, which is discussed in this publication. During the research works aimed at determining the effect of fine-grained silica on the rate of reaching 3.5 $\mathrm{MPa}$, or the WOC parameter, tests were carried out for four cement slurries formulas. One of the recipes was a control slurry that served as a reference point, the next three slurries were compositions containing 10\%, 20\% and 30\% of SBC fine-grained microsilica, respectively. During the preliminary tests, the effect of the applied additive on the technological parameters of the fresh cement slurry was determined. Then we focused on the values of early mechanical strength of the hardened cement slurry. The tests were carried out by non-destructive method using UCA under borehole-like conditions (temperature of $30^{\circ} \mathrm{C}$ and pressure of $5 \mathrm{MPa}$ ). We determined the compressive strength after a specified time (12, 42, 48 hours), and the time after which the compressive strength values were obtained (3 MPa, 3.5 MPa, $4 \mathrm{MPa}, 10 \mathrm{MPa}$ ). On the basis of the obtained results, the effect of fine-grained microsilica addition on the WOC parameter was determined, i.e. on the rate of reaching the strength value of $3.5 \mathrm{MPa}$.

Key words: recipe of cement slurry, waiting on cement, compressive strength, microsilica, fine-grained addition, ultrasonic cement analyzer.

\section{Wprowadzenie}

Celem uszczelniania otworów wiertniczych jest głównie ograniczenie międzystrefowej migracji płynów, np. wody słodkiej, solanki, gazu ziemnego, ropy naftowej, oraz uzyskanie szczelnego połączenia pomiędzy ścianami otworu wiertniczego a kolumną rur okładzinowych. Tworzący się z zaczynu płaszcz cementowy zapobiega korozji rur okładzinowych oraz chroni je przed obciążeniami wibracyjnymi powstającymi w trakcie dalszego wiercenia. Zadaniem stwardniałego zaczynu cementowego obecnego w przestrzeni pozarurowej jest również uszczelnienie strefy ucieczek płuczki w inne odcinki otworu, w których może dochodzić do komplikacji podczas dalszego wiercenia otworu (Kremieniewski, 2016, 2017; Kremieniewski i Rzepka, 2017). Wymaga się, aby zarówno technologia cementowania, jak też jakość zaczynu cementowego zapewniały jak najlepszą szczelność między kolumną rur okładzinowych a poziomem skał zbiornikowych. Zaczyny cementowe przeznaczone do uszczelniania kolumn rur okładzinowych hydratyzują w zróżnicowanych warunkach ciśnienia i temperatury (Bensted, 2004; Kremieniewski, 2018c). Zastosowanie jednego rodzaju zaczynu cementowego przy szerokim spektrum temperatur i ciśnień jest niewykonalne, dlatego też należy dysponować różnymi gatunkami zaczynów cementowych, których można będzie użyć w zróżnicowanych warunkach otworowych. Znaczną wagę przykłada się do jakości zaczynów cementowych stosowanych do cementowania kolumn rur eksploatacyjnych. Brak skutecznego uszczelnienia tych kolumn może mieć negatywny wpływ na późniejszą produktywność otworu, a niekiedy nawet uniemożliwić jego eksploatację (Gawlik i Szymczak, 2006; Bensted i Smith, 2008; Kremieniewski i Rzepka, 2016b). Zaczyn cementowy powinien wykazywać odpowiednią płynność przez czas potrzebny na przetłoczenie go przez kolumnę rur okładzinowych do uszczelnianego interwału pozarurowej przestrzeni pierścieniowej. Ponadto powinien charakteryzować się też odpowiednimi parametrami reologicznymi, niską wartością filtracji i odstoju wody i dostosowanym do warunków otworowych czasem wiązania (Habrat et al., 1980; Wiśniowski et al., 2007;
Stryczek et al., 2009, 2014; Kremieniewski, 2018b). Z kolei powstały z zaczynu płaszcz cementowy powinien charakteryzować się brakiem przepuszczalności dla gazu, niską wartością współczynnika porowatości oraz możliwie wysokimi wartościami parametrów mechanicznych, tj.: wytrzymałości na ściskanie, wytrzymałości na zginanie, przyczepności do rur stalowych oraz przyczepności do formacji skalnej (Kremieniewski et al., 2015; Kremieniewski i Rzepka, 2016a, 2018; Kremieniewski, 2018a).

Poruszając zagadnienie parametrów mechanicznych, należy nadmienić o wartości wynoszącej 3,5 MPa. W zaczynie cementowym po zatłoczeniu go $\mathrm{w}$ wypełnianą przestrzeń pierścieniową lub pozarurową rozpoczyna się proces hydratacji i wiązania, a co się z tym wiąże - także rozwój wytrzymałości na ściskanie (Kudowski, 2010; Kremieniewski, 2019a). Parametr ten jest niezwykle istotny szczególnie w początkowym okresie hydratacji, ponieważ od niego uzależniona jest możliwość przystąpienia do dalszych prac wiertniczych w otworze (Nelson et al., 1990; Stryczek et al., 2016; Kremieniewski i Stryczek, 2019). Opóźnienia w uzyskaniu odpowiedniej wartości wczesnej wytrzymałości na ściskanie skutkują wydłużeniem czasu prac spowodowanym koniecznością oczekiwania na związanie cementu (Kremieniewski, 2019b). W branży naftowej przyjęte jest, że minimalna wartość wczesnej wytrzymałości na ściskanie, po której uzyskaniu możliwe jest przystąpienie do dalszych prac po wykonaniu zabiegu cementowania, wynosi wspomniane 3,5 MPa i wartość tę określa się mianem WOC (z ang. waiting on cement) (Maier, 1965).

Określenie wartości WOC, czyli czasu potrzebnego na takie związanie zaczynu cementowego, po którym osiągnięta będzie minimalna wartość wytrzymałości na ściskanie, jest niezwykle istotne również do przeprowadzenia prac po cementowaniu czy do wykonania pomiarów geofizycznych. W przypadku przeprowadzenia ich zbyt wcześnie, czyli przed osiągnięciem wymaganej wytrzymałości mechanicznej płaszcza cementowego, „pomiar może nie odzwierciedlać rzeczywistego stanu zacementowania" (Jordan i Shepherd, 1985). Literatura (Floyd Farris, 1946; Jordan i Shepherd, 1985) podaje, że niekiedy dopuszczalne jest przyjęcie trzykrotnej wartości czasu 
gęstnienia zaczynu w warunkach otworowych jako czasu WOC. Jednak obecnie istnieje możliwość określenia czasu, po jakim zaczyn cementowy osiągnie wartość 3,5 MPa za pomocą nieniszczącej metody pomiaru w ultradźwiękowym analizatorze cementu - UCA (rys. 1). Urządzenie na podstawie pomiaru zmiany szybkości sygnału akustycznego umożliwia wykonywanie ciągłych nieniszczących badań wytrzymałości na ściskanie w trakcie wiązania zaczynu cementowego w warunkach otworopodobnych (Rzepka i Stryczek, 2008; Dębińska, 2013). Zaczyn umieszczany jest w komorze testowej, w której symulowane są warunki otworowe, czyli podwyższona temperatura oraz ciśnienie, a także czas osiągania tych parametrów zgodny z czasem niezbędnym do umieszczenia zaczynu w wypełnianej przestrzeni pierścieniowej. W komorze testowej sygnał akustyczny jest transmitowany przez próbkę cementu. Biorąc pod uwagę fakt, że wytrzymałość próbki wzrasta z czasem, to sygnał akustyczny przemieszcza się coraz szybciej przez próbkę. Ciepło dostarczane jest do komory przez wewnętrzny płaszcz grzewczy. Pomiar temperatury zaczynu przeprowadza się przy użyciu termopary. Programowalny zespół kontroli temperatury automatycznie kontroluje prędkość wzrostu temperatury, natomiast po osiągnięciu wymaganej temperatury program utrzymuje ją na stałym poziomie. Nastawy ciśnienia utrzymywane są poprzez regulowane zawory sprężonego powietrza dostarczanego z butli pod ciśnieniem. Zakres pomiarowy aparatu pozwala na prowadzenie badań w temperaturze do $204^{\circ} \mathrm{C}$, natomiast maksymalne ciśnienie pracy wynosi $35 \mathrm{MPa}$. Aparat podłączony jest do komputera z zainstalowanym oprogramowaniem. Wszystkie dane są zapisywane w programie i istnieje możliwość ich odczytania w czasie rzeczywistym oraz zachowywania w arkuszach oraz odczytywania w formie obrazów graficznych. Na uzyskanym z pomiarów rysunku (rys. 2) widoczne są wartości wytrzymałości na ściskanie w jednostce czasu oraz zaznaczone wartości wytrzymałości po upływie określonego czasu.

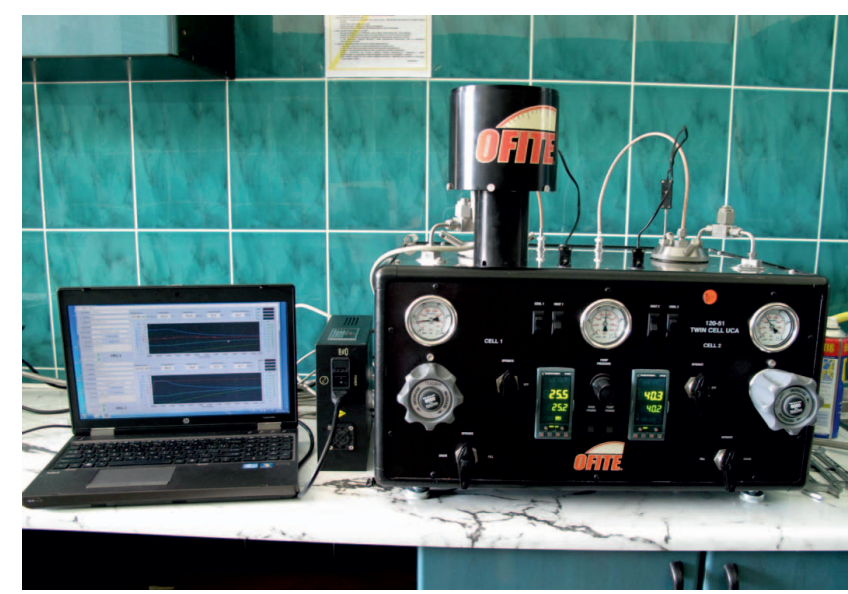

Rys. 1. Ultradźwiękowy analizator cementu (UCA)

Fig. 1. Ultrasonic Cement Analyzer

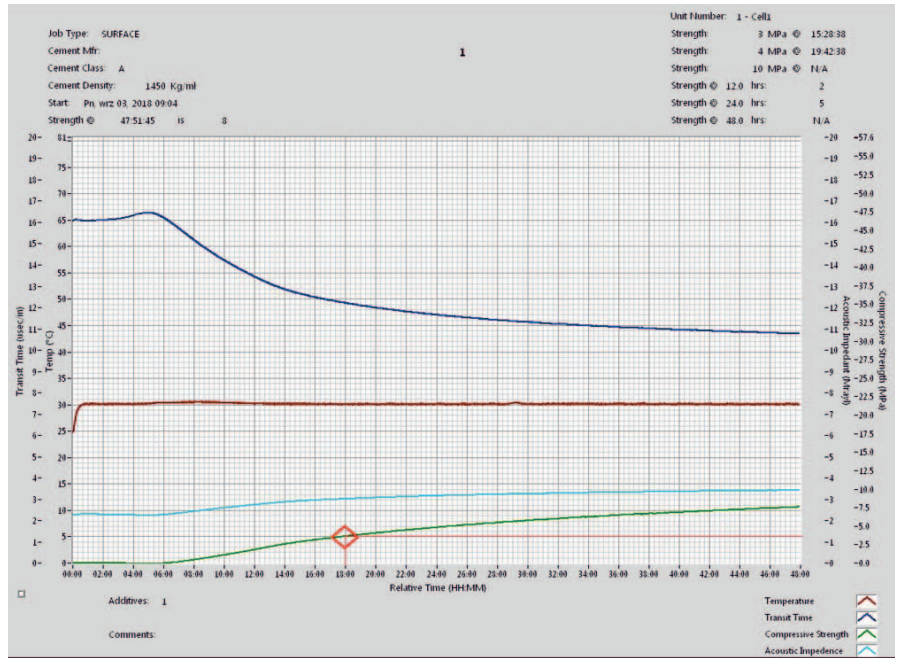

Rys. 2. Wykres narastania wytrzymałości na ściskanie podczas pomiaru za pomocą ultradźwiękowego analizatora cementu

Fig. 2. Graph of the increase of compressive strength during measurement using an ultrasonic cement analyzer

Należy mieć na uwadze, że wartość WOC zależy od wielu czynników, do których należą między innymi: temperatura i ciśnienie hydratacji, rodzaj zastosowanego cementu, współczynnik wodno-cementowy, skład ilościowy i jakościowy dodatków i domieszek modyfikujących pozostałe parametry technologiczne zaczynu oraz czas tłoczenia. Wzrastające wymagania odnośnie do stwardniałego zaczynu wymuszają poszukiwanie materiałów, które pozwolą na uzyskanie możliwie najlepszych wyników. Poszukiwane są innowacyjne rozwiązania, które pozwolą na otrzymanie wysokiej klasy produktu. Krzemionka jako dodatek do zaczynów jest produktem powszechnie stosowanym i ogólnodostępnym. Jednak omawiana w niniejszej publikacji mikrokrzemionka SBC charakteryzuje się bardzo wysokim współczynnikiem powierzchni właściwej, dzięki czemu zaczyn cementowy z tego rodzaju środkiem wykazuje odmienne właściwości niż standardowe zaczyny z mikrokrzemionką dotychczas stosowaną. W związku z powyższym w dalszej części publikacji omówiony został wpływ drobnoziarnistej krzemionki SBC na szybkość osiągnięcia wartości WOC.

\section{Przebieg prac badawczych}

Prace badawcze, podczas których określono wpływ drobnoziarnistej krzemionki na szybkość osiągnięcia wartości WOC, zrealizowane zostały w Laboratorium Zaczynów Uszczelniających INiG - PIB na podstawie norm: PN85/G-02320 Cementy i zaczyny cementowe do cementowania w otworach wiertniczych; PN-EN 10426-2 Przemyst naftowy i gazowniczy. Cementy i materiały do cementowania otworów. Część 2: Badania cementów wiertniczych oraz API SPEC 10 Specification for materials and testing for well cements. 
W celu określenia wpływu drobnoziarnistej krzemionki na szybkość osiągnięcia wartości 3,5 MPa przez stwardniały zaczyn cementowy, czyli parametru WOC, przeprowadzone zostały badania dla 4 receptur zaczynów cementowych. Aby porównać parametry świeżych i stwardniałych zaczynów, sporządzono jeden zaczyn kontrolny (zaczyn nr 1), który nie miał w składzie dodatku mączki krzemionkowej. Natomiast kolejne receptury zaczynów, oznaczone numerami 2, 3 oraz 4, zawierały dodatek $10 \%, 20 \%$ oraz $30 \%$ drobnoziarnistej mączki krzemionkowej SBC. W celu określenia wpływu stosowanej mączki krzemionkowej (krzemionki drobnoziarnistej) wszystkie zaczyny posiadały taki sam skład, a do sporządzenia zaczynu użyto takiej samej ilości wody. Badania parametrów reologicznych oraz gęstości zaczynu przeprowadzono w temperaturze pokojowej, natomiast badanie narastania wczesnej wytrzymałości mechanicznej po określonym czasie oraz wyznaczenie wartości WOC wykonano w temperaturze $30^{\circ} \mathrm{C}$ oraz pod ciśnieniem $5 \mathrm{MPa}$.

Tabela 1. Składy wytypowanych zaczynów dla warunków otworowych z temperaturą około $30^{\circ} \mathrm{C}$ i ciśnieniem około $5 \mathrm{MPa}$

Table 1. Composition of selected cement slurries for borehole conditions with a temperature of about $30^{\circ} \mathrm{C}$ and a pressure of about $5 \mathrm{MPa}$

\begin{tabular}{|l|c|c|c|c|}
\hline \multicolumn{1}{|c|}{ SKLAD } & $\begin{array}{c}\text { ZACZYN 1 } \\
\text { wzorcowy }\end{array}$ & ZACZYN 2 & ZACZYN 3 & ZACZYN 4 \\
\hline \hline Współczynnik wodno-cementowy & $\mathrm{w} / \mathrm{c}=0,64$ & $\mathrm{w} / \mathrm{c}=0,64$ & $\mathrm{w} / \mathrm{c}=0,64$ & $\mathrm{w} / \mathrm{c}=0,64$ \\
\hline Bentonit (bwow) & $0,3 \%$ & $0,3 \%$ & $0,3 \%$ & $0,3 \%$ \\
\hline Środek odpieniający & $1,0 \%$ & $1,0 \%$ & $1,0 \%$ & $1,0 \%$ \\
\hline Środek upłynniający & $0,3 \%$ & $0,3 \%$ & $0,3 \%$ & $0,3 \%$ \\
\hline Środek antyfiltracyjny & $0,3 \%$ & $0,3 \%$ & $0,3 \%$ & $0,3 \%$ \\
\hline Lateks & $10,0 \%$ & $10,0 \%$ & $10,0 \%$ & $10,0 \%$ \\
\hline Stabilizator lateksu & $2,0 \%$ & $2,0 \%$ & $2,0 \%$ & $2,0 \%$ \\
\hline Środek skracający czas gęstnienia & $3,5 \%$ & $3,5 \%$ & $3,5 \%$ & $3,5 \%$ \\
\hline Mączka krzemionkowa SBC & - & $10,0 \%$ & $20,0 \%$ & $30,0 \%$ \\
\hline Mikrocement & $20,0 \%$ & $20,0 \%$ & $20,0 \%$ & $20,0 \%$ \\
\hline Mikrosfera & $20,0 \%$ & $20,0 \%$ & $20,0 \%$ & $20,0 \%$ \\
\hline Cement CEM I 42,5R & $100,0 \%$ & $100,0 \%$ & $100,0 \%$ & $100,0 \%$ \\
\hline
\end{tabular}

Warunki takie przyjęto ze względu na fakt, że zaczyn zaprojektowano do uszczelniania otworów o takiej temperaturze i ciśnieniu. Materiałem wiążącym podczas projektowania zaczynów cementowych był cement klasy CEM I 42,5R. Wybór ten warunkowany był stosowaniem tego rodzaju spoiwa w warunkach przemysłowych. Matrycę cementową doszczelniono, wykorzystując we wszystkich recepturach dodatek mikrocementu w ilości 20\%. Stosowano stały iloraz wodno-cementowy równy 0,64 . Składników takich jak środek antyfiltracyjny i upłynniający użyto w stałych ilościach wynoszących 0,3\% (bwoc ${ }^{1}$ ) (tab. 1). Zastosowano lateks w stałej dla wszystkich receptur ilości równej 10\% (bwoc) oraz stabilizator lateksu w ilości 2\% (bwoc). Zaczyny sporządzono na 3-procentowym zasoleniu $\mathrm{KCl}\left(\right.$ bwow $^{2}$ ) wody zarobowej. Środka odpieniającego użyto w koncentracji 1\% (bwoc), optymalną wartość czasu gęstnienia uzyskano dzięki użyciu 3,5\% chlorku wapnia. Z uwagi na to, że projektowane receptury były zaczynami o obniżonej gęstości, zastosowano dodatek $20 \%$ mikrosfery glinokrzemianowej, a w celu ograniczenia frakcjonowania dodano $0,3 \%$ (bwow) bentonitu. Zaczyny

\footnotetext{
${ }^{1}$ bwoc - w stosunku do ilości cementu ( $\mathrm{z}$ ang. by weight of cement)

${ }^{2}$ bwow - w stosunku do ilości wody ( $\mathrm{z}$ ang. by weight of water)
}

oznaczone numerami 2, 3 i 4 posiadały dodatek mączki krzemionkowej w ilościach odpowiednio: 10\%, 20\% oraz 30\%, co pozwoliło określić wpływ zastosowanego $\mathrm{SiO}_{2}$ na szybkość osiągnięcia wartości 3,5 MPa przez stwardniały zaczyn cementowy. Szczegółowe ilości poszczególnych składników zestawiono w tabeli 1.
Po sporządzeniu wytypowanych receptur zaczynów pierwszym rodzajem parametrów, jakie poddano analizie, były parametry reologiczne. Na podstawie uzyskanych wartości naprężeń ścinających wykreślone zostały parametry opisane według wybranego modelu reologicznego, których wartości zestawiono w tabeli 2. Na podstawie obserwacji wartości zestawionych w tabeli 2 stwierdzono, że badane parametry znajdują najlepsze odwzorowanie poprzez model reologiczny Herschela-Bulkleya oraz częściowo poprzez model Cassona. Analizując wpływ dodatku poddanej badaniom mączki krzemionkowej na parametry reologiczne, zaobserwowano trend wzrostowy zarówno granicy płynięcia opisywanej modelem Herschela-Bulkleya, jak i współczynnika konsystencji ${ }_{\mathrm{HB}}$ pod wpływem wzrastającej koncentracji mączki krzemionkowej (tab. 1, rys. 2). Wartość granicy płynięcia w zaczynie bazowym wynosiła 22,4 Pa i wzrosła do 83,5 Pa po wprowadzeniu do receptury zaczynu największej z badanych, 30-procentowej koncentracji mączki krzemionkowej. Z kolei współczynnik konsystencji w zaczynie bazowym wynosił $0,1 \mathrm{~Pa} \cdot \mathrm{s}^{\mathrm{n}}$, natomiast obecność mączki krzemionkowej powodowała wzrost wartości współczynnika konsystencji do $130,2 \mathrm{~Pa} \cdot \mathrm{s}^{\mathrm{n}}$ po zastosowaniu $30 \% \mathrm{SiO}_{2}$. Takie zachowanie zaczynu pod wpływem dodatku krzemionki drobnoziarnistej należy mieć na uwadze i wymaga to zastosowania dodatkowej porcji środka dyspergującego. 
Tabela 2. Parametry zaczynów cementowych

Table 2. Cement slurry parameters

\begin{tabular}{|c|c|c|c|c|c|}
\hline \multirow{2}{*}{ Model reologiczny } & \multirow{2}{*}{ Badany parametr } & \multicolumn{4}{|c|}{ Zaczyn nr } \\
\hline & & 1 & 2 & 3 & 4 \\
\hline \multirow{2}{*}{$\begin{array}{c}\text { Model } \\
\text { Newtona }\end{array}$} & Lepkość dynamiczna $[\mathrm{Pa} \cdot \mathrm{s}]$ & 0,1817 & 0,2151 & 0,2508 & 0,2913 \\
\hline & Współczynnik korelacji [-] & 0,8988 & 0,0000 & 0,0000 & 0,0000 \\
\hline \multirow{3}{*}{$\begin{array}{c}\text { Model } \\
\text { Binghama }\end{array}$} & Lepkość plastyczna $[\mathrm{Pa} \cdot \mathrm{s}]$ & 0,1469 & 0,1337 & 0,1254 & 0,1402 \\
\hline & Granica płynięcia [Pa] & 22,4770 & 62,5651 & 80,9561 & 97,5759 \\
\hline & Współczynnik korelacji [-] & 0,9997 & 0,9727 & 0,8390 & 0,8495 \\
\hline \multirow{3}{*}{$\begin{array}{c}\text { Model } \\
\text { Ostwalda de Waele'a }\end{array}$} & Współczynnik konsystencji $\left[\mathrm{Pa} \cdot \mathrm{s}^{\mathrm{n}}\right]$ & 12,8717 & 30,9579 & 43,3924 & 62,3881 \\
\hline & Wykładnik potęgowy [-] & 0,2978 & 0,2172 & 0,2120 & 0,2088 \\
\hline & Współczynnik korelacji [-] & 0,8582 & 0,9433 & 0,9815 & 0,9919 \\
\hline \multirow{3}{*}{$\begin{array}{l}\text { Model } \\
\text { Cassona }\end{array}$} & Lepkość Cassona $[\mathrm{Pa} \cdot \mathrm{s}]$ & 0,0724 & 0,0504 & 0,0458 & 0,0484 \\
\hline & Granica płynięcia [Pa] & 15,1472 & 39,5656 & 61,3424 & 75,3787 \\
\hline & Współczynnik korelacji [-] & 0,9898 & 0,9954 & 0,9212 & 0,9276 \\
\hline \multirow{4}{*}{$\begin{array}{c}\text { Model } \\
\text { Herschela-Bulkleya }\end{array}$} & Granica płynięcia [Pa] & 22,4543 & 39,8914 & 49,2043 & 83,5000 \\
\hline & Współczynnik konsystencji $\left[\mathrm{Pa} \cdot \mathrm{s}^{\mathrm{n}}\right]$ & 0,1481 & 2,1588 & 61,4852 & 130,245 \\
\hline & Wykładnik potęgowy [-] & 0,9988 & 0,5995 & 0,1932 & 0,1177 \\
\hline & Współczynnik korelacji [-] & 0,9997 & 0,9965 & 0,9816 & 0,9961 \\
\hline
\end{tabular}

Jednak podczas realizowanych prac badawczych nie zwiększano ilości plastyfikatora $\mathrm{w}$ celu wyeliminowania dodatkowej zmiennej, która wprowadziłaby błąd pomiaru wynikający ze zmiany składu zaczynu. Z kolei analizując wartości lepkości opisywanej modelem Cassona, zaobserwowano obniżenie wartości wraz ze wzrostem koncentracji dodatku krzemionki drobnoziarnistej, co przedstawiono na rysunku 3.

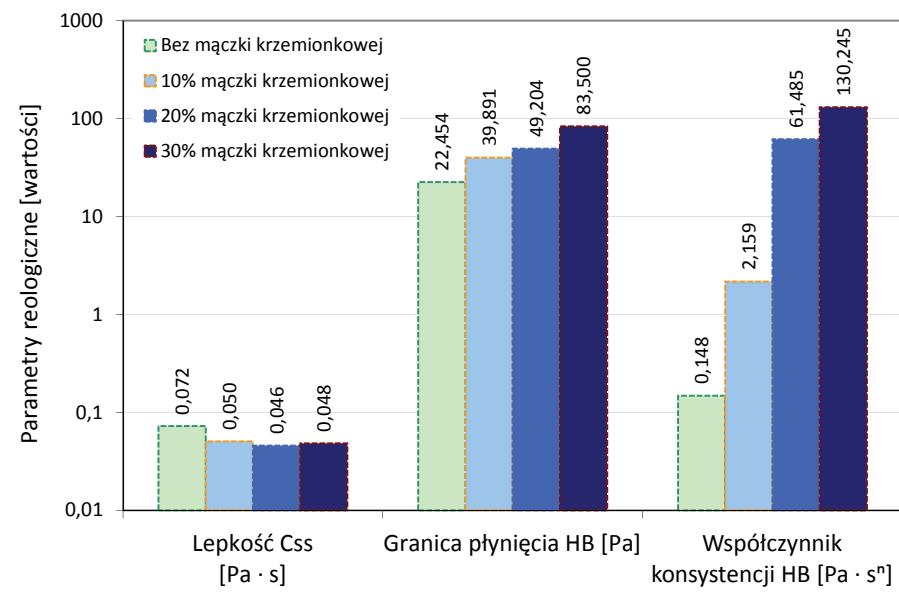

Rys. 3. Zestawienie wybranych wartości parametrów reologicznych

Fig. 3. Summary of selected values of rheological parameters

Na rysunku 4 zestawiono wykresy wartości krzywych płynięcia obrazujące przebieg naprężeń ścinających wraz ze wzrostem prędkości ścinania, pod wpływem wzrastającej koncentracji mączki krzemionkowej w zaczynie. Analizując uzyskane wyniki, widać zwiększanie się wartości naprężeń ścinających wskutek wzrastającej ilości mączki krzemionkowej. Przy czym najbardziej widoczny wzrost naprężeń ścinających obserwowany jest przy niskich prędkościach ścinania. Takie zachowanie zaczynu może być korzystne pod względem utrzymywania lekkich frakcji mikrosfery, co zapobiega nadmiernemu frakcjonowaniu zaczynu lekkiego.

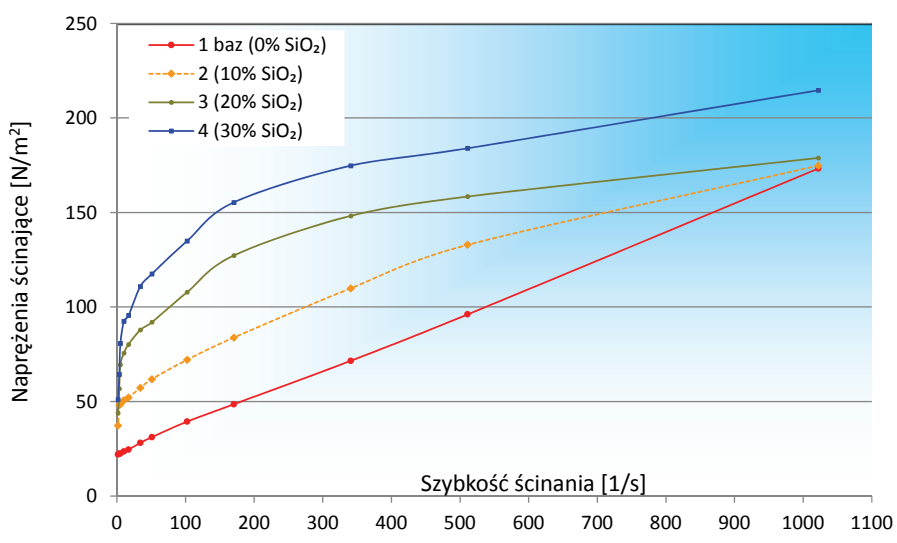

Rys. 4. Przebieg wartości krzywych płynięcia analizowanych zaczynów w zależności od koncentracji mączki krzemionkowej

Fig. 4. The waveform of the values of flow curves of the analyzed cement slurries depending on the concentration of silica powder

Analizując zestawione w tabeli 3 wyniki badań parametrów zaczynów, zaobserwowano, że 10-procentowe (bwoc) zwiększenie koncentracji mączki krzemionkowej w zaczynie powoduje wzrost gęstości zaczynu o $30 \mathrm{~kg} / \mathrm{m}^{3}$.

W przypadku próbek stwardniałych zaczynów odnotowano wzrost wytrzymałości na ściskanie wraz ze wzrostem udziału krzemionki drobnoziarnistej dla próbek hydratyzujących 
Tabela 3. Parametry badanych receptur zaczynów dla warunków otworowych z temperaturą około $30^{\circ} \mathrm{C}$ i ciśnieniem około $5 \mathrm{MPa}$ Table 3. Parameters of the tested cement slurry recipes for borehole conditions with a temperature of about $30^{\circ} \mathrm{C}$ and a pressure of about $5 \mathrm{MPa}$

\begin{tabular}{|c|c|c|c|c|c|}
\hline \multicolumn{2}{|c|}{ Parametr } & $\begin{array}{c}\text { ZACZYN } 1 \\
\text { wzorcowy }\end{array}$ & ZACZYN 2 & ZACZYN 3 & ZACZYN 4 \\
\hline \multicolumn{2}{|c|}{ Gęstość $\left[\mathrm{kg} / \mathrm{m}^{3}\right]$} & 1470 & 1500 & 1530 & 1560 \\
\hline \multirow{3}{*}{$\begin{array}{c}\text { Wartość wczesnej } \\
\text { wytrzymałości na ściskanie } \\
{[\mathrm{MPa}]}\end{array}$} & po 12 godzinach hydratacji & 4,0 & 6,0 & 7,0 & 8,0 \\
\hline & po 24 godzinach hydratacji & 8,0 & 10,0 & 11,0 & 12,0 \\
\hline & po 48 godzinach hydratacji & 11,0 & 14,0 & 15,0 & 16,0 \\
\hline \multirow{3}{*}{$\begin{array}{c}\text { Czas, po jakim zaczyn uzyskał } \\
\text { wytrzymałość na ściskanie } \\
\text { [godz.:min] }\end{array}$} & $3 \mathrm{MPa}$ & $10: 22$ & $7: 15$ & $5: 21$ & $5: 14$ \\
\hline & $4 \mathrm{MPa}$ & $12: 11$ & $8: 37$ & $6: 28$ & $6: 16$ \\
\hline & $10 \mathrm{MPa}$ & $35: 30$ & 24:09 & $19: 52$ & $17: 16$ \\
\hline Czas osiągnięcia wartości WOC & $3,5 \mathrm{MPa}$ & $11: 16$ & $7: 56$ & $5: 54$ & $5: 45$ \\
\hline \multirow{3}{*}{ Parametry reologiczne } & Lepkość $_{\mathrm{Css}}[\mathrm{Pa} \cdot \mathrm{s}]$ & 0,0724 & 0,0504 & 0,0458 & 0,0484 \\
\hline & Granica płynięcia $_{\mathrm{HB}}[\mathrm{Pa}]$ & 22,4543 & 39,8914 & 49,2043 & 83,5000 \\
\hline & Współczynnik konsystencji $\mathrm{H}_{\mathrm{HB}}\left[\mathrm{Pa} \cdot \mathrm{s}^{\mathrm{n}}\right]$ & 0,1481 & 2,1588 & 61,4852 & 130,245 \\
\hline
\end{tabular}

w temperaturze $30^{\circ} \mathrm{C}$ i pod ciśnieniem $5 \mathrm{MPa}$. Przy czym najbardziej widoczny przyrost wytrzymałości obserwowany jest po wprowadzeniu pierwszej 10-procentowej porcji mączki krzemionkowej i wynosi on od $2 \mathrm{MPa}$ do $3 \mathrm{MPa}$ w porównaniu do próbki kontrolnej (rys. 5). Natomiast wzrost koncentracji $\mathrm{SiO}_{2}$ z wartości $10 \%$ do wartości $20 \%$ skutkuje przyrostem wytrzymałości na ściskanie wynoszącym $1 \mathrm{MPa}$, analogiczny wzrost wartości wytrzymałości obserwowano przy zmianie koncentracji mączki krzemionkowej z 20\% (bwoc) na $30 \%$ (bwoc), co przedstawiono na rysunku 5 oraz w tabeli 3.

Porównując zestawione w tabeli 3 (zaznaczenie) wartości czasu, po jakim zaczyn uzyskiwał określone wartości wytrzymałości na ściskanie, wynoszące odpowiednio $3 \mathrm{MPa}, 4 \mathrm{MPa}$ oraz $10 \mathrm{MPa}$, zaobserwowano skracanie czasu przyrostu wczesnej wytrzymałości na ściskanie wraz ze wzrostem koncentracji mączki krzemionkowej w recepturze zaczynu. Przy czym podobnie jak w przypadku analizowanego wcześniej przyrostu wytrzymałości na ściskanie tak samo podczas analizy czasu, po którym uzyskano określoną wartość wytrzymałości, najbardziej wyraźną zmianę otrzymano po wprowadzeniu pierwszej (10-procentowej) koncentracji mączki krzemionkowej. Kolejne wartości również powodowały skrócenie czasu niezbędnego do osiągnięcia wymaganej wartości wytrzymałości (zarówno wartości $3 \mathrm{MPa}, 4 \mathrm{MPa}$, jak i $10 \mathrm{MPa}$ ), lecz proces ten zachodził mniej gwałtownie.

Rozważając wpływ drobnoziarnistej krzemionki na szybkość osiągnięcia wartości WOC, czyli czasu niezbędnego do takiego związania zaczynu, że płaszcz cementowy będzie wykazywał wytrzymałość na ściskanie równą 3,5 MPa, stwierdzono, że najmocniejsze skrócenie czasu następuje po zastosowaniu 10-procentowej i 20-procentowej koncentracji mączki krzemionkowej w zaczynie. Zaczyn kontrolny oznaczony numerem 1 uzyskał wytrzymałość 3,5 MPa po czasie

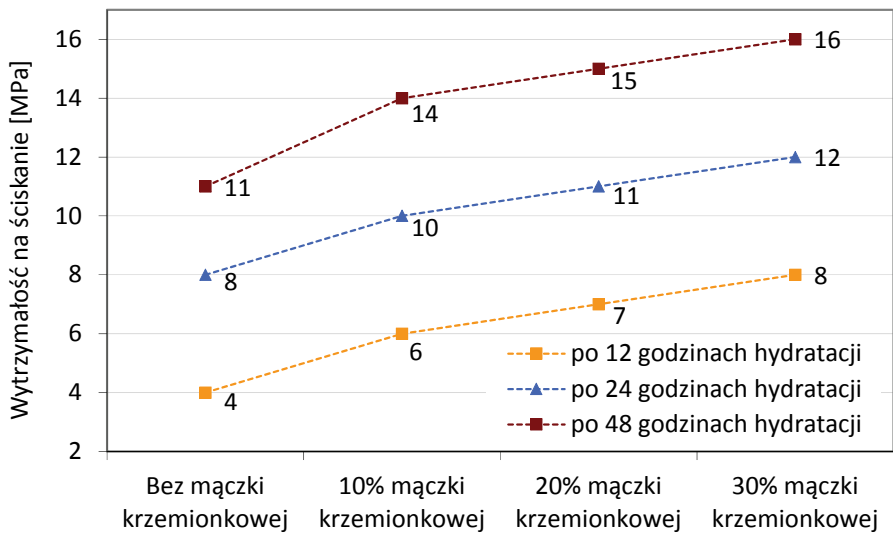

Rys. 5. Zestawienie wartości wytrzymałości na ściskanie w początkowym okresie hydratacji w zależności od koncentracji $\mathrm{SiO}_{2}$

Fig. 5. Comparison of compressive strength values in the initial hydration period, depending on the $\mathrm{SiO}_{2}$ concentration

11 godzin i 16 minut. Wprowadzenie do zaczynu 10\% mączki krzemionkowej spowodowało skrócenie czasu niezbędnego do osiągnięcia wartości 3,5 MPa o ponad 3 godziny w porównaniu do zaczynu bazowego - uzyskano czas WOC równy 7 godzin 56 minut. 20-procentowa ilość mączki krzemionkowej spowodowała kolejne, ok. 2-godzinne skrócenie czasu osiągnięcia wartości 3,5 MPa - uzyskano czas WOC wynoszący 5 godzin 54 minuty. Natomiast największa z badanych ilość mikrokrzemionki SBC, wynosząca 30\% (bwoc) powodowała tylko 9-minutowe skrócenie czasu osiągania WOC w porównaniu do zaczynu zawierającego $20 \% \mathrm{SiO}_{2}$ (otrzymano czas $\mathrm{WOC}=5$ godz. 45 min.). Wyniki badań czasu osiągania wartości 3,5 MPa przez zaczyn zestawiono na rysunku 6.

Na podstawie uzyskanych wyników badań, stwierdzono, że obecność drobnoziarnistej mączki krzemionkowej SBC w zaczynie cementowym prowadzi do wzrostu gęstości sporządzanego zaczynu lekkiego o $30 \mathrm{~kg} / \mathrm{m}^{3}$ przypadające na 


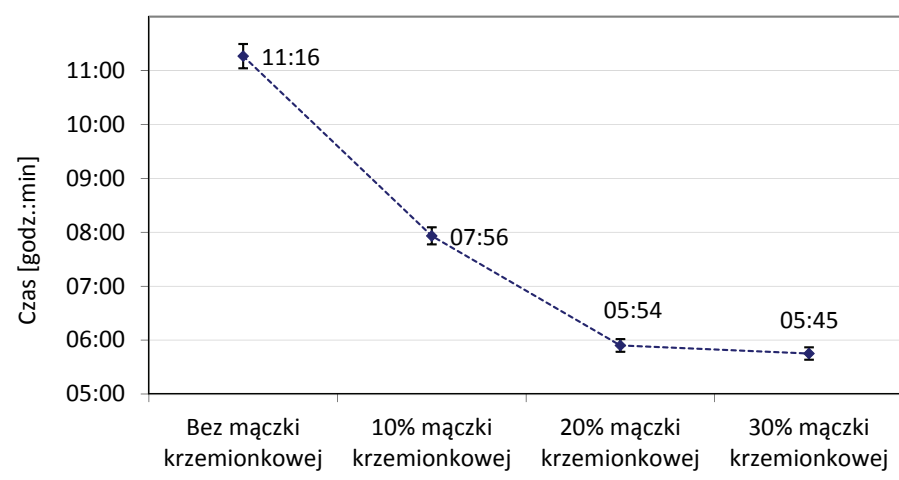

Rys. 6. Wartości czasu, po jakim zaczyn uzyskał wartość wytrzymałości na ściskanie 3,5 MPa (WOC - waiting on cement)

Fig. 6. Time values after which the cement slurry obtained the compressive strength value of $3.5 \mathrm{MPa}$ (WOC - waiting on cement)

każde 10\% mączki krzemionkowej. Stosowana podczas badań drobnoziarnista krzemionka SBC powoduje wzrost granicy płynięcia zaczynu oraz współczynnika konsystencji, natomiast w niewielkim stopniu obniża lepkość zaczynu opisywaną modelem Cassona. Dodatek $\mathrm{SiO}_{2} \mathrm{w}$ formie drobnoziarnistej skutkuje wzrostem parametrów mechanicznych stwardniałego zaczynu cementowego oraz przyspiesza czas niezbędny do uzyskania określonych wartości (3 MPa, $4 \mathrm{MPa}, 10 \mathrm{MPa}$ ) wczesnej wytrzymałości mechanicznej. Dodatkowo zaobserwowano, że najefektywniejsza ilość mączki krzemionkowej, która powoduje zarówno korzystne działanie na wzrost parametrów mechanicznych stwardniałego zaczynu, jak też optymalne skrócenie czasu osiągania wartości 3,5 MPa, to koncentracja wynosząca 10\% w stosunku do masy cementu. Dalszy wzrost również prowadzi do uzyskania pożądanych rezultatów, jednak nie jest to korzystne ekonomicznie.

Rozpatrując wyniki badań stwardniałych zaczynów cementowych, zaobserwowano bardzo korzystny wpływ drobnoziarnistej krzemionki SBC na skrócenie czasu osiągania wartości 3,5 MPa przez stwardniały zaczyn cementowy. Przy zastosowaniu najmniejszej z badanych koncentracji, wynoszącej $10 \%$ w stosunku do masy cementu, możliwe jest osiągnięcie korzystnych parametrów mechanicznych i technologicznych zaczynu, co może mieć wpływ na przyspieszenie realizacji dalszych prac po wykonaniu zabiegu cementowania.

\section{Wnioski}

Analizując wpływ dodatku drobnoziarnistej krzemionki SBC na parametry świeżego i stwardniałego zaczynu cementowego, stwierdzono, że:

- obecność drobnoziarnistej mączki krzemionkowej typu SBC w recepturze lekkiego zaczynu cementowego powoduje wzrost gęstości o $30 \mathrm{~kg} / \mathrm{m}^{3}$ przypadające na każde $10 \%$ mączki krzemionkowej SBC;

- drobnoziarnista mączka krzemionkowa powoduje mocny wzrost współczynnika konsystencji oraz granicy płynięcia opisywanych modelem Herschela-Bulkleya, natomiast nie wykazuje znacznego wpływu na lepkość opisywaną modelem Cassona;

- wzrastające ilości mączki krzemionkowej w recepturze płynnego zaczynu cementowego powodują wzrost naprężeń ścinających głównie przy niskich wartościach szybkości ścinania, co może korzystnie wpływać na poprawę stabilności sedymentacyjnej;

- dodatek mączki krzemionkowej SBC powoduje wzrost wartości wczesnej wytrzymałości na ściskanie w przypadku próbek powstałych z zaczynu lekkiego hydratyzującego w temperaturze $30^{\circ} \mathrm{C}$ i pod ciśnieniem $5 \mathrm{MPa}$;

- drobnocząsteczkowa mikrokrzemionka SBC powoduje skrócenie czasu osiągania początkowych wartości wytrzymałości mechanicznej;

- dodatek mączki krzemionkowej SBC wykazuje mocny wpływ na skrócenie czasu WOC (osiągania wartości 3,5 MPa), co jest bardzo korzystne z punktu widzenia wcześniejszego przystępowania do prac po zabiegu cementowania;

- ze względu na wzrost parametrów reologicznych pod wpływem wypełniaczy drobnoziarnistych należy mieć na uwadze konieczność wykorzystania dodatkowych porcji środków dyspergujących w celu dostosowania parametrów reologicznych do warunków tłoczenia zaczynu;

- uzyskane wyniki zaprezentowanych prac badawczych świadczą o korzystnym działaniu mączki krzemionkowej SBC $w$ przedstawionym zaczynie lekkim, jednak w przypadku innej receptury wyniki mogą się znacznie różnić, w związku z czym niezbędne jest prowadzenie indywidualnych badań laboratoryjnych dla konkretnej receptury zaczynu.

Artykuł powstał na podstawie pracy badawczej pt. Analiza możliwości doszczelnienia mikrostruktury plaszcza cementowego za pomoca nowych domieszek drobnoziarnistych - praca INiG - PIB na zlecenie MNiSW; nr zlecenia: 0044/KW/2019, nr archiwalny: DK-4100-0034/2019.

\section{Literatura}

Bensted J., 2004. Cementy wiertnicze. Cz. 2. Stosowanie cementów wiertniczych do cementowania odwiertów. Cement Wapno Beton, 2: 61-72.

Bensted J., Smith J.R., 2008. Cementy wiertnicze z historycznej perspektywy. Cement Wapno Beton, 3: 124-135.

Dębińska E., 2013. Wyznaczanie statycznej wytrzymałości strukturalnej i wczesnej wytrzymałości mechanicznej zaczynów cementowych. Nafta-Gaz, 2: 134-142. 
Floyd Farris R., 1946. Method for Determining Minimum Waitingon-cement Time. Society of Petroleum Engineers. DOI: 10.2118/946175-G

Gawlik P., Szymczak M., 2006. Migracje gazowe w przestrzeniach międzyrurowych otworów realizowanych na przedgórzu Karpat. Nafta-Gaz, 7-8: 349-358.

Habrat S., Raczkowski J., Zawada S., 1980. Technika i technologia cementowań w wiertnictwie. Wydawnictwa Geologiczne, Warszawa: 1-498.

Jordan M.E., Shepherd R.A., 1985. Cement Bond Log: Determining Waiting-on-Cement Time. Society of Petroleum Engineers. DOI: 10.2118/14200-MS.

Kremieniewski M., 2016. Ograniczenie ekshalacji gazu w otworach wiertniczych poprzez modyfikację receptur oraz kształtowanie się struktury stwardniałych zaczynów uszczelniających. Prace Naukowe Instytutu Nafty i Gazu - Państwowego Instytutu Badawczego, 199: 1-400.

Kremieniewski M., 2017. Poprawa stabilności sedymentacyjnej zaczynu cementowego. Nafta-Gaz, 4: 242-249. DOI: 10.18668/ NG.2017.04.04.

Kremieniewski M., 2018a. Poprawa wczesnej wytrzymałości mechanicznej płaszcza cementowego powstałego z zaczynu lekkiego. Nafta-Gaz, 8: 606-612. DOI: 10.18668/NG.2018.08.06.

Kremieniewski M., 2018b. Wpływ środków regulujących czas wiązania na parametry reologiczne zaczynu cementowego. Nafta-Gaz, 11: 828-838. DOI: 10.18668/NG.2018.11.07.

Kremieniewski M., 2018c. Zmiana parametrów technologicznych zaczynu cementowego pod wpływem przeciwsedymentacyjnego dodatku żywicy ksantanowej. Nafta-Gaz, 12: 927-937. DOI: 10.18668/NG.2018.12.07.

Kremieniewski M., 2019a. O konieczności prowadzenia serwisowych badań parametrów technologicznych zaczynów uszczelniających. Nafta-Gaz, 1: 48-55. DOI: 10.18668/NG.2019.01.07.

Kremieniewski M., 2019b. Korelacja wyników badań filtracji i wczesnej wytrzymałości mechanicznej zaczynów cementowych z dodatkiem maczkki krzemionkowej. Nafta-Gaz, 7: 394-403. DOI: 10.18668/NG.2019.07.03.

Kremieniewski M., Rzepka M., 2016a. Korelacja parametrów charakteryzujących strukturę porowa kamieni cementowych badanych za pomoca porozymetrii rtęciowej oraz mikrotomografii komputerowej. Nafta-Gaz, 12: 1076-1083. DOI: 10.18668/ NG.2016.12.10.

Kremieniewski M., Rzepka M., 2016b. Przyczyny i skutki przepływu gazu w zacementowanej przestrzeni pierścieniowej otworu wiertniczego oraz metody zapobiegania temu zjawisku. Nafta-Gaz, 9, 722-278. DOI: 10.18668/NG.2016.09.06.

Kremieniewski M., Rzepka M., 2017. Celowość prowadzenia prac badawczych nad nowymi środkami obniżającymi filtrację zaczynów cementowych. Nafta-Gaz, 8: 583-590. DOI: 10.18668/ NG.2017.08.05
Kremieniewski M., Rzepka M., 2018. Poprawa szczelności płaszcza cementowego za pomocą innowacyjnych dodatków antymigracyjnych. Nafta-Gaz, 6: 8-15. DOI: 10.18668/NG.2018.06.06.

Kremieniewski M., Rzepka M., Stryczek S., Wiśniowski R., Kotwica Ł., Złotkowski A., 2015. Korelacja przepuszczalności i parametrów opisujących strukturę stwardniałych zaczynów cementowych stosowanych do uszczelniania otworów w rejonie Basenu Pomorskiego. Nafta-Gaz, 10: 737-746. DOI: 10.18668/ NG2015.10.04

Kremieniewski M., Stryczek S., 2019. Zastosowanie cementu wysokoglinowego do sporządzania zaczynów uszczelniających w technologiach wiertniczych. Cement Wapno Beton, 3: 215-226.

Kudowski W., 2010. Chemia cementu i betonu, Wydawnictwo Naukowe PWN, Warszawa: 1-700.

Maier L.F., 1965. Understanding Surface Casing Waiting-on-Cement Time. PETSOC-65-03-05. DOI: 10.2118/65-03-05.

Nelson E.B. et al., 1990. Well Cementing, Schlumberger Educational Service, Houston, Texas, USA.

Rzepka M., Stryczek S., 2008. Laboratoryjne metody określania parametrów technologicznych świeżych zaczynów uszczelniających przed zabiegiem związanym z procesem uszczelniania kolumn rur okładzinowych w otworach wiertniczych. Wiertnictwo, Nafta, Gaz, 25(2): 625-636.

Stryczek S., Wiśniowski R., Gonet A., Ferens W., 2009. Parametry reologiczne świeżych zaczynów uszczelniających w zależności od czasu ich sporządzania. Wiertnictwo, Nafta, Gaz, 26(1-2): 369-382.

Stryczek S., Wiśniowski R., Gonet A., Złotkowski A., 2014. The influence of time of rheological parameters of fresh cement slurries. AGH Drilling, Oil, Gas, 31(1): 123-133.

Stryczek S. (red.), Wiśniowski R., Uliasz-Misiak B., Złotkowski A., Kotwica Ł., Rzepka M., Kremieniewski M., 2016. Studia nad doborem zaczynów uszczelniających w warunkach wierceń w basenie pomorskim. Wydawnictwa Akademii Górniczo-Hutniczej, Kraków.

Wiśniowski R., Stryczek S., Skrzypaszek K., 2007. Kierunki rozwoju badań nad reologią płynów wiertniczych. Wiertnictwo, Nafta, Gaz, 24: 595-607.

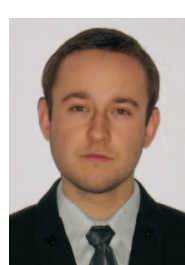

Dr inż. Marcin KREMIENIEWSKI

Adiunkt w Zakładzie Technologii Wiercenia Instytut Nafty i Gazu - Państwowy Instytut Badawczy ul. Lubicz $25 \mathrm{~A}$

31-503 Kraków

E-mail: marcin.kremieniewski@inig.pl 